\title{
PELAKSANAAN ASURANSI KECELAKAAN LALU LINTAS PADA PT. JASA RAHARJA CABANG SULAWESI TENGGARA PERWAKILAN KOLAKA
}

\author{
Syamsul Bahri \\ Universitas 19 November Kolaka
}

\begin{abstract}
Abstrak
Penelitian ini bertujuan untuk mengetahui pengajuan klaim dan proses pemberian santunan Asuransi Sosial Kecelakaan Lalu Lintas Jalan. Penelitian ini merupakan penelitian deskriptif dan apabila dilihat dari tujuannya termasuk penelitian hukum empiris. Dalam penelitian ini penulis mengambil lokasi penelitian di PT (Persero) Jasa Raharja Sulawesi Tenggara Perwakilan Kolaka. Jenis data yang dipergunakan meliputi data primer dan data skunder. Tehnik pengumpulan data yang dipergunakan yaitu wawancara dan penelitian kepustakaan baik berupa buku-buku, artikel-artikel, peraturan perundangundangan, dan makalah dan dokumen kepustakan lainnya serta Kepustakaan Yang bersumber dari lokasi penelitian berupa buku-buku dan artikel-artikel serta dokumen. Analisa data menggunakan Analisis data kualitatif dengan model interaktif.

Berdasarkan hasil penelitian ini diperoleh hasil bahwa pengajuan klaim dan pemberian santunan kecelakaan lalu lintas jalan berdasarkan pada UU No. 34 Tahun 1964 jo PP No. 18 Tahun1965. Pemberian santunan yang diberikan terhadap korban kecelakaan lalu lintas jalan berdasarkan pasal 11 PP No. 18 Tahun 1964, Surat Keputusan Menteri Keuangan RI No. 416/KMK.06/2001 serta didasarkan pada Keputusan Direksi. Santunan kecelakaan lalu lintas jalan akan diberikan kepada setiap orang yang berada diluar alat angkutan lalu lintas jalan yang menimbulkan kecelakaan, yang menjadi korban akibat kecelakaanyang disebabkan alat angkutan lalu lintas jalan tersebut, dengan pengecualianyang tercantum dalam pasal 13 PP No. 18 Tahun1965. Pelaksanaan Asuransi Sosial Kcelakaan Lalu Lintas Jalan merupakan suatu upaya pemerintah dalam memberikan perlindungan jaminan sosial kepada masyarakat khususnya korban kecelakaan lalu lintas jalan. Pihak Jasa Raharja tetap memberikan dana santunan kepada korban kecelakaan lalu lintas jalan yang disebabkan oleh alat angkutan lalu lintas jalan yang lalai membayar sumbangan wajib, yang kemudian pihak Jasa Raharja dapat menuntu balik kepada pemilik kendaraan penyebab kecelakaan yang lalai dalam pembayaran sumbangan wajib untuk membayar semua penggantian kerugian yang telah dikeluarkan oleh Jasa Raharja. Mengenai hal ini diatur dalam Pasal 14 huruf d PP No. 18 Tahun 1965.

Implikasi teoritis ini adalah adanya pembaharuan dalam pengaturan asuransi sosial kecelakaan lalu lintas jalan, yaitu merubah dan melengkapi UU No. 34 Tahun 1964 jo PP No. 18 Tahun 1965, sedangkan implikasi praktisnya adalah hasil penelitian ini dapat dipakai sebagai rujukan pelaksanaan asuransi sosial kecelakaan lalu lintas jalan oleh PT (persero) Jasa Raharja Sulawesi Tenggara Perwakilan Kolaka dalam pelaksanaan Asuransi sosial Kecelakaan Lalu Lintas Jalan.
\end{abstract}

Kata Kunci : Asuransi, Perjanjian 


\section{A. Pendahuluan}

Manusia dalam kehidupannya senantiasa menghadapi kemungkinan terjadinya suatu musibah yang dapat melenyapkan dirinya atau berkurangnya nilai ekonomi seseorang. Keadaan ini dapat tejadi baik terhadap diri sendiri, keluarga, atau perusahaan yang diakibatkan meninggal dunia, kecelakaan, sakit, atau kehilangan fungsi suatu benda seperti kecelakaan, kehilangan dan juga kebakaran. Asuransi merupakan persiapan yang dibuat untuk menghadapi kerugian sebagai sesuatu yang tidak dapat diduga. Apabila kerugian itu menimpa salah seorang anggota dari kelompok tersebut, maka kerugian itu akan ditanggung bersama. Kebutuhan masyarakat terhadap perlindungan atas risiko-risiko yang mungkin dihadapi itu tidak selalu sama, tergantung pada perkembangan yang terjadi dalam masyarakat yang bersangkutan itu sendiri.

Pada kenyataannya, asuransi sosial sebenarnya masih merupakan suatu kenyataan yang relatif muda. Mula pertumbuhan dan perkembangannya pun berlandaskan atas kebutuhan masyarakat akan suatu jaminan sosial. Keadaan ekonomi yang buruk, maka masyarakat merasa adanya suatu kebutuhan jaminan sosial yang lebih besar dan lebih terjamin. Selanjutnya diberbagai negara atas dasar memberikan jaminan sosial itulah, mulai pada dikembangkan pola asusansi sosial, yang pada dasarnya memberikan perlindungan kepada masyarakat luas, terhadap semua kemungkinan kerugian yang diderita di luar kemampuan orang-orang pribadi.

Di Indonesia, asuransi sosial merupakan salah satu bagian dari asuransi pada umumnya, yang relatif masih baru, lebih baru dari jenis asuransi yang lain. Asuransi sosial disebut "baru" baik asuransi sosial sebagai obyek ilmu pengetahuan, sebagai kelembagaan sendiri, asuransi sosial itu memang relatif lebih baru apabila dibandingkan dengan jenis asuransi sosial lain pada umumnya. Ini dapat dimengerti, karena timbulnya suatu gagasan. Terciptanya asuransi sosial memang tidak sama dengan asuransi lain pada umumnya. Oleh karena asuransi sosial menitikberatkan pada suatu tujuan guna memenuhi kebutuhan akan jaminan sosial atau social security dalam masyarakat, maka tepatlah apabila asuransi jenis ini disebut sebagai asuransi sosial, meskipun ada sementara sarjana yang mempergunakan istilah asuransi wajib. Pada dasarnya dapat dikatakan bahwa tujuan asuransi sosial itu memang berkaitan dengan perlindungan terhadap jaminan sosial terhadap masyarakat.

Pengenalan asuransi sosial di Indonesia saat sesuai dengan usahausaha pemerintah untuk mewujudkan program kesejahteraan sosial, dalam rangka lebih menjamin akan adanya kesejahteraan masyarakat luas. Sebagai contoh dapat kiranya dipakai sebagai titik tolak yaitu penjelasan resmi dari Undang-undang No. 34 Tahun 1964 tentang dana kecelakaan lalu lintas jalan, dimana dijelaskan dengan tegas bahwa pertimbangan pemerintah di dalam membuat undang-undang ini ialah bertitik tolak pada "Social Security" atau jaminan sosial.

Pemerintah mengadakan pertanggungan yang diatur oleh undang-undang ini, bertujuan memikul secara gotong-royong risiko-rsiko dari teknik modern alatalat pengangkutan yang menimpa masyarakat. Di samping sejarah dan latar belakang yang berbeda antara asuransi pada umumnya dengan 
asuransi sosial, maka terdapat perbedaan yang asasi antara keduanya ialah mengenai dasar terjadinya/terbentuknya asuransi sosial dengan asuransi pada umumnya.

Asuransi pada umumnya, terjadi didasari atas adanya kata sepakat dan perjanjian antara tertanggung dan penanggung karena adanya kata sepakat antara kedua pihak. Perjanjian tersebut memang dikehendaki oleh para pihak yang bersangkutan. Para pihakpun terdiri dari subyek hukum pribadi atau hukum perdata. Peranan kehendak para pihak dalam menentukan terjadinya perjanjian serta atas dasar sukarela itulah merupakan faktor utama guna terjadinya perjanjian tersebut. Tidak ada unsur lain di luar kehendak para pihak. Asuransi sosial terjadi antara "tertanggung" dan "penanggung" itu tidak di dasari atas adanya kata sepakat ; tidak pula atas dasar sukarela, tetapi atas dasar adanya suatu ketentuan dan peraturan atau undang-undang yang mengharuskan terjadinya suatu ikatan hubungan hukum antara "tertanggung dan penanggung". Undang-undang tersebut dapat menentukan bahwa sesuatu perbuatan itu berlaku bagi seluruh warga negara atau sebagian dari warga negara. Anggota masyarakat (sebagai tertanggung) menutupi perjanjian dengan penanggung (yang biasanya adalah suatu badan/organisasi yang diatur/ada hubungannya dengan pemerintah). Dengan demikian dapat disimpulkan bahwa dalam asuransi sosial di samping unsur-unsur yang harus dipenuhi dalam hukum asuransi pada umumnya, maka harus dipenuhinya suatu unsur ialah adanya unsur "wajib".

\section{B. Pengertian \\ 1. Pengertian Pelaksanaan}

Pelaksanaan adalah suatu proses tentang suatu runtunan perubahan dan atau peristiwa dalam perkembangan sesuatu. (Suharso Dkk, 2005: 392), dan menurut Adi Satrio bahwa pelaksanaan itu dapat diartikan sebagai jalur-jalur atau tahapan-tahapan penyelesaian dalam suatu masalah; cara bekerja, Sedangkan proses adalah merupakan suatu rangkaian tindakan operasional terhadap suatu peristiwa dan atau tahapan-tahapan dalam suatu peristiwa pembentukan dsb; jalannya; bekerjanya; rangkaian kerja(Adi Satrio, 2005: 484), dan proses menurut Ana Retnoningsih bahwa proses adalah tahap kegiatan untuk menyelesaikan suatu aktivasi.

\section{Pengertian Operasional}

Sebelum mengkaji lebih jauh tentang pelaksanaan Asuransi Sosial dalam Kecelakaan lalu lintas di kabupaten Kolaka terlebih dahulu ada beberapa hal yang perlu kita pahami sebagai sesuatu hal yang begitu urgen sebagai indikator dasar yakni Opersional dalam penelitian ini sebagai penunjang utama dalam memecahkan masalah yang terdapat di dalamnya dan adapun beberapa pengertian operasional yang dimaksud adalah sebagai berikut :

1. Pelaksanaan adalah proses pembayaran yang diberikan kepada korban kecelakaan lalu lintas jalan.

2. Asuransi atau pertanggungan adalah perjanjian antara 2 (dua) pihak atau lebih dimana pihak tertanggung mengikat diri kepada penanggung, dengan menerima premi-premi Asuransi untuk memberi penggantian kepada tertanggung karena kerugian, kerusakan atau kehilangan keuntungan yang di 
harapkan atau tanggung jawab hukum kepada pihak ketiga yang mungkin akan di derita tertanggung karena suatu peristiwa yang tidak pasti, atau untuk memberi pembayaran atas meninggal atau hidupnya seseorang yang dipertanggungkan.

3. Lalu Lintas adalah Suatu gerak perpindahan dari satu tempat ke tempat yang lain yang dilakukan secara berulang-ulang.

4. Korban/Tetanggung adalah orang yang mengenderai kendaraan atau tidak, yang mengalami musibah kecelakaan di jalan.

5. Dana adalah dana yang terhimpun dari sumbangan wajib yang dipungut dari pemilik / pengusaha angkutan lalu lintas jalan yang sediakan untuk menutup akibat keuangan karena kecelakaan lalu lintas jalan kepada korban atau ahli waris yang bersangkutan.

6. Perikatan adalah Suatu perhubungan hukum antara dua orang atau dua pihak,berdasarakan mana pihak yang satu berhak menuntut sesuatu hal dari pihak yang lain, dan pihak yang lain berkewajiban untuk memenuhi tuntutan itu.

7. perjanjian adalah suatu peristiwa dimana seorang berjanji kepada seorang lain atau dimana dua orang itu saling berjanji untuk melaksanakan sesuatu hal, timbullah suatu hubungan antara dua orang tersebut yang dinamakan perikatan.

8. Risiko adalah bahaya, Kemungkinan, kerugian; akibat kurang menyenangkan dari sesuatu perbuatan usaha dan sebagainya atau risiko adalah kewajiban memikul kerugian yang disebabkan karena suatu kejadian diluar kesalahan salah satu pihak. Berarti persoalan risiko itu berpokok pangkal pada terjadinya suatu peristiwa di luar kesalahan salah satu pihak yang mengadakan perjanjian.

9. Proses adalah merupakan suatu rangkaian tindakan operasional terhadap suatu peristiwa dan atau tahapan-tahapan dalam suatu peristiwa pembentukan, jalannya, bekerjanya, rangkaian kerja.

Berdasarkan pengertian di atas, maka pengertian pelaksanaan yang atau berkaitan dengan judul skripsi ini adalah proses atau tahapantahapan yang merupakan suatu rangkaian tindakan operasional terhadap suatu peristiwa dan atau tahapan-tahapan dalam suatu peristiwa pembentukan dsb; jalannya; bekerjanya; rangkaian kerja harus dilakukan dalam menyelesaikan suatu masalah perasuransian pada PT. Jasa Raharja (Persero) Cabang Kendari perwakilan Kolaka.

Proses dalam hal ini diartikan sebagai berikut:

"Suatu rangkaian tindakan operasional terhadap suatu peristiwa dan atau tahapan-tahapan dalam suatu peristiwa pembentukan dsb ; jalannya ; bekerjanya ; rangkaian kerja

\section{Hal-Hal Yang Berkaitan Dengan Asuransi}

Asuransi / pertanggungan adalah perjanjian antara 2 (dua) pihak atau lebih dimana pihak tertanggung mengikat diri kepada penanggung, dengan menerima premi-premi Asuransi untuk memberi penggantian kepada tertanggung karena kerugian, kerusakan atau kehilangan 
keuntungan yang di harapkan atau tanggung jawab hukum kepada pihak ketiga yang mungkin akan di derita tertanggung karena suatu peristiwa yang tidak pasti, atau untuk memberi pembayaran atas meninggal atau hidupnya seseorang yang dipertanggungkan, dapat kita lihat Undang-undan No. 34 Tahun 1964 Pasal 4 (1):

"Setiap orang yang menjadi korban mati dan atau cacad tetap akibat kecelakaan yang disebabkan oleh alat angkutan lalu lintas jalan tersebut akan diberi dana kerugian kepadanya atau kepada ahli warisnya sebesar jumlah yang ditentukan berdasarkan

pemerintah.”(2)“Untuk

melaksanakan ganti rugi kepada korban menurut ketentuan tersebut dalam ayat (1) pasal ini Menteri dapat menunjuk instansi pemerintah yang dianggap perlu"

Dengan melihat pengertian yang ada di atas, berbicara tentang asuransi berarti kita berbicara tentang perjanjian dan akan melahirkan perikatan seperti apa yang kami kutip dalam buku Subekti pada halaman 1 dengan judul 'Hukum Perjanjian' mengatakan bahwa:

"perjanjian adalah suatu peristiwa dimana seorang berjanji kepada seorang lain atau dimana dua orang itu saling berjanji untuk melaksanakan sesuatu hal, timbullah suatu hubungan antara dua orang tersebut yang dinamakan perikatan.

Perjanjian itu menerbitkan suatu perikatan antara dua orang yang membuatnya

dalam bentuknya, perjanjian itu berupa suatu rangkaian perkataan yang

mengandung janji-janji atau kesanggupan yang diucapkan atau ditulis".
Dengan demikian dapat diartikan bahwa asuransi merupakan perjanjian yang mana antara kedua belah pihak mengikatkan dirinya satu sama lain dan atau dapat berarti pula sebagai suatu peristiwa dimana seorang berjanji kepada seseorang untuk melaksanakan sesuatu hal. Maka dengan ini penulis kiranya menganggap penting untuk memasukkan hal-hal yang berkaitan dengan asuransi yaitu berupa bentuk perjanjian dan atau bentuk perikatan serta apa yang menjadi dasar-dasar perjanjian maupun syarat-syarat itu sendiri sehingga kita dapat meletakkan asuransi sebagai salah satu bagian dari hukum perjanjian dalam bidang keperdataan dan adapun hal-hal yang berkaitan dengan asuransi adalah sebagai berikut :

\section{Perikatan Dan Perjanjian Serta Hubungannya}

Suatu perikatan adalah Suatu perhubungan hukum antara dua orang atau dua pihak, berdasarkan mana pihak yang satu berhak menuntut sesuatu hal dari pihak yang lain, dan pihak yang lain berkewajiban untuk memenuhi tuntutan itu. Pihak yang berhak menuntut sesuatu, dinamakan Kreditur atau si berpiutang, sedangkan pihak yang berkewajiban memenuhi tuntutan dinamakan Debitur atau si berutang, sedangkan suatu perjanjian adalah suatu peristiwa dimana seorang berjanji kepada seorang lain atau dimana dua orang itu saling berjanji untuk melaksanakan sesuatu hal, timbullah suatu hubungan antara dua orang tersebut yang dinamakan perikatan, Perjanjian itu menerbitkan suatu perikatan antara dua orang yang membuatnya. Perjanjian itu berupa suatu rangkaian perkataan yang mengandung janji-janji atau 
kesanggupan yang diucapkan atau ditulis. Dengan demikian, hubungan antara perikatan dan perjanjian adalah bahwa perjanjian itu menerbitkan perikatan dan perjanjian adalah sumber perikatan disamping sumber-sumber lain.

Adapun Jenis-jenis Perikatan adalah sebagai berikut :

1. Perikatan positif yaitu Perikatan yang prestasinya berupa perbuatan nyata, misalnya memberi atau berbuat sesuatu.

2. Perikatan Negatif yaitu perikatan yang prestasinya berupa tidak berbuat sesuatu, misalnya tidak akan mendirikan gedung

3. perikatan sepintas lalu (sementara) yaitu perikatan yang prestasinya cukup hanya dilakukan dalam satu perbuatan saja dan dalam waktu yang singkat karena tujuan perikatan telah dicapai. Misalnya jual beli

4. Perikatan berkelanjutan (terus menerus) yaitu perikatan yang prestasinya bersifat terus menerus dalam jangka waktu tertentu, misalnya sewa menyewa, perjanjian kerja.

5. Perikatan alternatif yaitu perikatan dimana debitur berkewajiban melaksanakan satu dari dua atau lebih prestasi yang dipilih, misalnya A boleh melever semen atau kayu dan atau batu merah.

Sedangkan jenis-jenis perjanjian pada umumnya terbagi 2 ( dua) macam yaitu:

\section{Perjanjian Obligator}

Perjanjian obligator adalah suatu perjanjian dimana mengharuskan dan atau mewajibkan seseorang membayar atau menyerahkan sesuatu, dan adapun jenis-jenis perjanjian obigator ini di bagi lagi menjadi beberapa macam yaitu: a. Perjanjian sepihak, ialah perjanjian yang hanya ada kewajiban pada satu pihak dan hanya ada hak pada pihak lain. Contoh: perjanjian hibah, perjanjian pinjam pakai.

b. Perjanjian timbal balik, ialah perjanjian dimana hak dan kewajiban ada pada kedua belah pihak. Jadi pihak yang berkewajiban melakukan suatu prestasi juga berhak menuntut suatu kontra prestasi. Contoh: perjanjian jual beli, perjanjian sewa menyewa.

c. Perjanjian Cuma-Cuma, ialah perjanjian dalam mana pihak yang satu memberikan suatu keuntungan kepad pihak lain dengan tiada mendapatkan nikmat dri padanya. Contoh perjanjian hibah.

d. Perjanjian atas beban, ialah perjanjian yang mewajibkan masing-masing pihak memberikan prestasi (memberikan sesuatu, berbuat sesuatu, dan tidak berbuat sesuatu). Contoh: jual beli, sewa menyewa.

e. Perjanjian konsensuil, ialah perjanjian yang mengikat sejak adanya kesepakatan (konsensus) dari kedua belah pihak. Jadi perjanjian lahir sejak detik tercapainya kata sepakat dari kedua belah pihak. Contoh: Jual beli, sewa menyewa.

f. Perjanjian riil, ialah perjanjian yang mengikat jika disertai dengan perbuatan/tindakan nyata. Jadi dengan adanya kata sepakat saja, perjanjian tersebut belum mengikat kedua belah pihak. Contoh: 
Perjanjian penitipan barang, perjanjian pinjam pakai.

g. Perjanjian formil, ialah perjnjian yang terikat pada bentuk tertentu, jadi bentuknya tidak sesuai dengan ketentuan-ketentuan, mka perjanjian tersebut tidak sah. Contoh: Jual beli tanah harus dengan akte PPAT, pendirian Perseroan Terbatas harus dengan akte Notaris.

h. Perjanjian bernama, ialah perjanjian yang khusus ditur dan disebutkan dalam KUH Perdata buku III bab V s/d Bab XVII dan dalam KUHD (Kitab Undang-Undang Hukum Dagang). Contoh: Perjanjian jual beli, sewa menyewa, penitipan barang, pinjam pakai, asuransi, perjanjian pengangkutan.

\section{Perjanjian non obligator.}

Perjanjian non obligator adalah Perjanjian yang tidak mengharuskan seseorang membayar / menyerahkan sesuatu. Dan peranjian non obligator ini terbagi pula beberapa macam yaitu sebagai berikut:

a. Zakelijk overeenkomst, ialah perjanjian yang menetapkan dipindahkannya suatu hak dari seseorang kepada orang lain. Jadi obyek perjanjian adalah hak. Contoh : Balik nama hak atas tanah.

b. Bevifs overeenkomst atau procesrechlijk, overenkomst, ialah perjanjian untuk membuktikan sesuatu. Perjanjian ini umumnya ditujukan pada hakim, tak terjadi perselisihan, supaya memakai alat bukti yang menyimpang dari apa yang ditentukan oleh undangundang.

c. Liberatoir overenkomst, ialah perjanjian dimana seseorang membebaskan pihak lain dari suatu kewajiban.

d. Vaststelling overekomst, ialah perjanjian untuk mengkhiri keraguan mengenai isi dan luas perhubungan hukum antara kedua belah pihak.

Di samping itu kiranya penulis masukkan pula tentang unsur-unsur perjanjian sehingga dapat diletakkan dasar-dasar asuransi dalam perjanjian itu sendiri dan unsur-unsur perjanjian itu adalah sebagai berikut:

1. Essentialia, ialah unsur yang sangat esensi/penting dalam suatu perjanjian yang harus ada. Misalnya: Di dalam perjanjian harus ada kata sepakat antara kedua belah pihak.

2. Naturalia, ialah unsur perjanjian yang sewajarnya ada jika tidak dikesampingkan oleh kedua belah pihak.

Misalnya: Menurut pasal 1474 KUH perdata dalam perjanjian jual beli barang, penjual wajib menjamin cacat yang tersembunyi. Namun kewajiban ini dapat ditiadakan dengan kesepakatan kedua belah pihak.

3. Accidentalia, ialah unsur perjanjian yang ada jika dikehendaki oleh kedua belah pihak.Misanya: Perjanjian tidak dibutuhkan suatu bentuk tertentu, artinya perjanjian boleh dibuat dengan akte atau secara lisan. 


\section{Syarat Sah Perjanjian}

Adapun untuk sahnya suatu perjanjian diperluhkan empat syarat yaitu :

a. Sepakat mereka yang mengikatkan dirinya, artinya sepakat dalam hal ini berarti kedua belah pihak menyatakan diri baik itu berupa pernyataan lisan maupun berupa akte dengan substansi saling berjanji untuk berbuat sesuatu atau tidak berbuat sesuatu dalam waktu yang telah ditentukan oleh kedua belah pihak (Subekti, 1984: 37) atau dengan sepakat yang dimaksudkan bahwa pihakpihak yang mengadakan perjanjian itu harus sepakat, setuju, seiya sekata mengenai hal-hal yang pokok dari perjanjian yang diadakan itu.

b. Cakap untuk membuat suatu perjanjian, artinya setiap orang cakap dalam hal ini berarti memiliki kemampuan untuk melakukan perbuatan hukum, seseorang dianggap memiliki kemampuan melakukan perbuatan hukum bila dia telah dewasa menurut 330 KUHPerdata yang berbunyi: "belum dewasa adalah anak tidak lebih dahulu telah kawin". (R. Tjitrosudibio Dkk, 1999: 90). Namun demikian tidak semua orang diperbolehkan bertindak sendiri dalam melaksanakan kewenangan hukumnya yang oleh hukum menggolongkan orang yang tidak cakap melakukan tindakan hukum (handelingsonbekwaam), yakni seperti di cantumkan dalam pasal 1330 KUH
Perdata yaitu sebagai berikut

1. Orang yang belum dewasa (minderjarige), maksudnya adalah mereka yang belum mencapai umur genap 21 (dua puluh satu) tahun, dan tidak lebih dahulu telah kawin (pasal 330 ayat KUHPdt). Apabila perkawinan itu dibubarkan sebelum umur mereka genap dua puluh satu tahun, maka mereka tidak kembali lagi dalam kedudukan belum dewasa (pasal 330 ayat 2 KUHPdt). Orang yang belum dewasa apabila memenuhi syarat-syarat tertentu dapat mohon pendewasaan agar mereka dapat melakukan tindakan hukum.

2. Mereka yang ditaruh di bawah pengampunan, maksudnya adalah mereka yang ditaruh di bawah pengampunan yakni orang dewasa yang selalu berada dalam keadaan dungu, sakit otak atau mata gelap/buta meskipun kadang-kadang cakap memperggunakan pikirannya, dengan demikian mereka yang berada di bawah pengampunan apabila bertindak secara hukum maka haruslah diwakili pengampu/Curatornya.

3. Orang-orang perempuan yang sudah berkeluarga, maksudnya adalah mereka (perempuan) yang ingin bertindak secara hukum haruslah diwakili oleh suaminya akan tetapi 
dengan berlakunya UU Perkawinan No. 1 Tahun 1974 maka pasal 1330 KUHPdt sub 3 ini tidak berlaku lagi, karena menurut UU Perkawinan No. 1 Tahun 1974 ini, masing-masing pihak (suami-istri) berhak melakukan perbuatan hukum yaitu terdapat pada pasal 31 ayat $2 \mathrm{UU}$ No. 1 Tahun 1974.(Komariah, 2002: 20)

c. Mengenai suatu hal tertentu, makna dari syarat tertentu disini adalah barang yang menjadi obyek perjanjian paling sedikit harus dapat ditentukan jenisnya, sedangkan jumlahnya tidak menjadi soal asalkan dapat ditentukan kemudian.(Komariah, 2002: 175)

d. Suatu sebab yang halal, adapun yang dimaksudkan disini ialah isi perjanjian itu sendiri termasuk jenis barangnya seperti narkoba. (Sakka Pati Dkk, 2008: 175), sedangkan yang dimaksud sebab halal adalah sebagaimana yang dijelaskan dalam pasal 1337 KUHPerdata yang berbunyi sebagai berikut:

"Suatu sebab adalah terlarang, apabila dilarang oleh undangundang, atau apabila berlawanan dengan kesusilaan dan atau ketertiban umum"

\subsection{Asas-asas perjanjian}

Penting juga penulis kemukakan tentang asas-asas suatu perjanjian yaitu sebagai berikut:

a. Asas Konsensualitas, artinya dengan adanya kata sepakat antara kedua belah pihak, perjanjian sudah mengikat. Jadi perikatan lahir sejak detik tercapainya kesepakatan.

b. Bentuk perjanjian bebas, artinya perjanjian tidak terikat pada bentuk tertentu. Jadi boleh diadakan secara tertulis, boleh dengan lisan dan sebagainya.

c. Kebebasan berkontrak, artinya setiap orang bebas membuat perjanjian yang terdapat dalam undang-undang yang dikenal sebagai perjanjian bernama, Misalnya : Sewa-menyewa,tukarmenukar dan sebagainya.

d. Apa yang diperjanjikan mengikat kedua belah pihak.(Komariah, 2002: 172)

\subsection{Risiko}

Menurut Drs. Adi Satrio, Risiko dalam kamus Ilmiah populer pada Halaman 520 diartikan mengandung bahaya dan menurut Kamus Besar Bahasa Indonesia Karangan Drs. Suharso dan Dra. Ana Retnoningsih halaman 431 risiko diartikan Kemungkinan, bahaya, kerugian; akibat kurang menyenangkan dari sesuatu perbuatan usaha dan sebagainya sedangkan menurut Prof. Subekti, S.H dalam bukunya yang berjudul Hukum Perjanjian pada halaman 59 mengatakan bahwa risiko adalah kewajiban memikul kerugian yang disebabkan karena suatu kejadian diluar kesalahan salah satu pihak. Berarti persoalan risiko itu berpokok pangkal pada terjadinya suatu peristiwa di luar kesalahan salah satu pihak yang mengadakan perjanjian. Dengan kata lain berpokok pangkal pada kejadian yang dalam hukum perjanjian dinamakan : keadaan memaksa. Persoalan risiko adalah buntut dari suatu keadaan memaksa, sebagaimana ganti rugi adalah buntut dari wanprestasi. Dalam bagian 
umum Buku III Kitab UndangUndang Hukum Perdata, sebenarnya kita hanya dapat menemukan satu pasal, yang sengaja mengatur soal risiko ini, yaitu pasal 1237. Pasal ini berbunyi sebagai berikut:

"Dalam hal adanya perikatan untuk memberikan suatu barang tertentu, maka barang itu semenjak perikatan dilahirkan, adalah atas tanggungan si berpiutang". Perkataan tanggungan dalam pasal ini sama dengan "risiko". Dengan begitu, dalam perikatan untuk memberikan suatu barang tertentu tadi, jika barang ini sebelum diserahkan,musnah karena suatu peristiwa di luar kesalahan salah satu pihak, kerugian ini harus dipikul oleh "si berpiutang", yaitu pihak yang berhak menerima barang itu. Suatu perikatan untuk memberikan suatu barang tertentu adalah suatu perikatan yang timbul dari suatu perjanjian yang sepihak. Pembuat undang-undang di sini hanya memikirkan suatu perjanjian di mana hanya ada satu kewajiban pada satu pihak, yaitu, kewajiban memberikan suatu barang tertentu, dengan tidak memikirkan bahwa pihak yang memikul kewajiban ini juga dapat menjadi pihak yang berhak atau dapat menuntut sesuatu. Dengan kata lain, pembuat undang-undang tidak memikirkan perjanjian yang timbalbalik, di mana pihak yang berkewajiban melakukan suatu prestasi juga berhak menuntut suatu kontraprestasi, berbicara tentang prestasi menurut pasal 1234 KUHPerdata yang berbunyi sebagai berikut:

"Tiap-tiap perikatan untuk memberikan sesuatu, untuk berbuat sesuatu atau tidak berbuat sesuatu".
D. Tinjauan Umum Tentang Asuransi Sosial.

1. Pengertian Asuransi Sosial

Asuransi Sosial, ialah asuransi yang memberikan jaminan kepada masyarakat dan diselenggarakan oleh pemerintah, yaitu:

a. Asuransi kecelakaan lalu lintas (jasa raharja).

b. Asuransi TASPEN, ASTEK.

ASKES, ASABRI.

2. Unsur-Unsur Sosial

Unsur asuransi social itu ada 4 yaitu:

a. Penanggung (biasanya suatu organisasi di bawah wewenang pemerintah)

b. Tertanggung (biasanya masyarakat luas anggota/golongan masyarakat tertentu.

c. Risiko (suatu kerugian yang sudah diatur dan ditentukan lebih dahulu) dan menurut subekti dalam bukunya yang berjudul Hukum Perjanjian pada halaman 59 mengtakan bahwa risiko diartikan, sebagai kewajiban memikul kerugian yang disebabkan karena suatu kejadian di luar keslahan salah satu pihak.

d. Wajib ( berdasarkan suatu ketentuan undang-undang atau peraturan lain), wajib maksudnya disini adalah Undang-undang No. 34 Tahun 1964 Jo. Peraturan Pemerintah Nomor 18 Tahun 1965 Pasal 2 Tentang Sumbangan wajib Yaitu:

(1)“Tiap

pengusaha dan atau 
pemilik alat angkutan lalu lintas jalan diwajibkan memberi sumbangan setiap tahunnya untuk dana kecelakaan lalu lintas jalan. Jumlah sumbangan wajib tersebut ditentukan oleh menteri menurut suatu tarif yang bersifat Progresif" pasal 3 (1)"Sumbangan wajib untuk satu tahun takwim harus sudah dibayar lunas selambat-lambatnya pada akhir bulan juni" (2)“Waktu dan cara pembayaran sumbangan wajib diatur lebih lanjut oleh Menteri"

Penyelenggaraan asuransi sosial biasanya merupakan suatu organisasi di bawah wewenang dan pengawasan negara. Jadi dalam hal ini negara berkedudukan sebagai penanggung sekaligus sebagai penguasa dan pengelola dana. Dengan demikian fungsi sosial dari asuransi sosial nampak jelas, yaitu di satu pihak asuransi ini menuju ke satu sistem jaminan sosual ialah untuk kesejahteraan masyarakat dan di lain pihak dana yang terkumpul dan yang dikuasai negara itu akan kembali lagi kepada masyarakat. Tujuan asuransi sosial itu terutama untuk menjamin terlindunginya kebutuhan akan jaminan sosial bagi masyarakat luas. Oleh karena itu yang menjadi atau berposisi sebagai tertanggung tentu saja masyarakat luas atau anggota golongan masyarakat luas. (Syamsul Anwar, 2007: 81) Ketentuan-ketentuan di dalam undang-undang dengan tegas sudah diatur dan meliputi suatu kerugian-kerugian yang sudah ditentukan pula sejak semula, sebagaimana ketentuan yang sudah dimuat dalam peraturan atau undangundang yang bersangkutan. Jadi dasar terbentuknya asuransi sosial itu bukan sematamata atas dasar adanya kata sepakat, tetapi karena adanya suatu peraturan tertentu. Biasanya peraturan tersebut sifatnya mewajibkan atau mengharuskan itu dengan jelas dan akan nampak pada setiap peraturan atau undang-undang yang bersangkutan.

\section{Asuransi}

Pertanggungan adalah perjanjian antara 2 (dua) pihak atau lebih dimana pihak tertanggung mengikat diri kepada penanggung, dengan menerima premipremi Asuransi untuk memberi penggantian kepada tertanggung karena kerugian, kerusakan atau kehilangan keuntungan yang di harapkan atau tanggung jawab hukum kepada pihak ketiga yang mungkin akan di derita tertanggung karena suatu peristiwa yang tidak pasti, atau untuk memberi 
pembayaran atas meninggal atau hidupnya seseorang yang dipertanggungkan.

Adapun jenis asuransi dapat diuraikan sebagai berikut:

\section{Asuransi Kerugian Menutup}

pertanggungan untuk kerugian karena kerusakan atau kemusnahan harta benda yang dipertanggungkan karena sebab-sebab atau kejadian yang dipertanggungkan (sebabsebab atau bahaya-bahaya yang disebut dalam kontrak atau polis asuransi). Dalam asuransi kerugian, penanggung menerima premi dari tertanggung dan apabila terjadi kerusakan atau kemusnahan atas harta benda yang dipertanggungkan maka ganti kerugian akan dibayarkan kepada tertanggung. Menutup pertanggungan untuk membayarkan sejumlah santunan karena meninggal atau tetap hidupnya seseorang dalam jangka waktu pertanggungan. Dalam asuransi jiwa, penanggung menerima premi dari tertanggung dan apabila tertanggung meninggal, maka santunan (uang pertanggungan) dibayarkan kepada ahli waris atau seseorang yang ditunjuk dalam polis sebagai penerima santunan. Yang diatur dalam Peraturan Pemerintah No. 18 Tahun 1965 pada Pasal 1 Point (g) yaitu

"Ahli Waris adalah hanya anak-anak, janda atau duda dan atau orang tua dari korban mati kecelakan lalu lintas jalan sebagaimana dimaksudkan dalam pasal 12 peraturan pemerintah ini" dan adapun bunyi Pasal 12 sebagaimana yang termaktub dalam pasal (1) diatas yaitu: (1)"Yang berhak mendapat pembayaran Dana dalam hal kematian korban adalah jandanya/dudanya yang sah; dalam hal tidak ada jandanya/dudanya yang sah, anak-anaknya yang sah, dalam hal tidak ada jandanya/dudanya dan anakanaknya yang sah, kepada orang-tuanya yang sah". (2) "Dalam hal korban tidak meninggal dunia, pembayaran Dana diberikan kepada korban".(3) "Hak untuk mendapat pembayaran Dana berdasarkan Undangundang No. 34 tahun 1964 tentang Dana Kecelakaan Lalu-lintas Jalan jo. Peraturan Pemerintah ini, tidak boleh diserahkan kepada fihak lain, digadaikan, atau dibuat tanggungan pinjaman, pun tidak boleh disita untuk menjalankan putusan hakim ataupun menjalankan pailisemen".

\section{Sumber Hukum Asuransi.} Menurut Subekti dalam KUHPerdata Pasal 1320 Letak dasar hukum dari pada hukum asuransi yaitu:

a. Terdapat dalam Kitab Undang-Undang Hukum Perdata (BW) pasal 1774, yang menyatakan sebagai berikut : Suatu persetujuan untunguntungan (kans overeenkomst) adalah suatu perusahaan yang hasilnya mengenai untung 
ruginya, baik bagi semua

pihak maupun bagi sebahagian pihak, bergantung kepada suatu kejadian yang belum tentu, misalnya: 1 . Persetujuan Asuransi, 2. Bunga cagak hidup, 3. Perjudian dan pertaruhan, 4. Persetujuan yang pertama (asuransi) diatur dalam KUH Dagang (WvK).

b. Persetujuan Asuransi diatur dialam dan diluar Kitab Undang-Undang Hukum Dagang (WvK) yaitu:

1. Dalam KUH Dagang (WvK):

a. Buku I,Bab IX: Asuransi pada umumnya Buku II, Bab X: Asuransi kebakaran, Asuransi pertanian, Asuransi jiwa.

b. Buku II, Bab IX: Asuransi Laut, Asuransi bahaya perbudakan.

c. Buku II, Bab Xpengangkutan darat, sungai dan pertanian, daratan.

2. Diluar KUH Dagang adalah perundang-undangan

Republik Indonesia:

a. Dana kecelakaan penumpang, UndangUndang No. 33 Tahun 1964.

b. Dana kecelakaan lalu lintas jalan, UndangUndang No. 34 tahun 1964.

c. Tabungan dan Asuransi Pegawai Negeri, Peraturan Pemerintah No. 10 tahun 1963.

d. Pendirian dan penunjukan perusahaan Asuransi berdasarkan, Peraturan
Pemerintah No. 4 tahun 1965

\section{Jenis-Jenis Asuransi}

Asuransi terbagi atas 3 bagian yaitu seperti dikutip dari Ananto Sun, 2006 halaman 79 , adalah sebagai berikut:

1. Asuransi kerugian adalah asuransi yang memberikan ganti rugi kepada tertanggung yang menderita kerugian barang atau benda miliknya, kerugian mana terjadi karena bencana atau bahaya terhadap mana pertanggungan ini diadakan, baik kerugian itu berupa:
a. Kehilangan nilai pakai atau
b. Kekurangan nilainya atau
c. Kehilangan keuntungan yang diharapkan oleh tertanggung. Penanggung tidak harus membayar ganti rugi kepadatertanggung kalau selama jangka waktu perjanjian obyek pertanggungan tidak mengalami bencana atau bahaya yang dipertanggungkan.

2. Asuransi jiwa adalah perjanjian tentang pembayaran uang dengan nikmat dari premi dan yang berhubungan dengan hidup atau matinya seseorang termasuk juga perjanjian asuransi kembali uang dengan pengertian catatan dengan perjanjian dimaksud tidak termasuk 
perjanjian asuransi kecelakaan (yang masuk dalam asuransi kerugian) berdasarkan pasal I a Bab I Staatblad (1941 - 101). Dalam asuransi jiwa (yang mengandung saving) penanggung akan tetap mengembalikan jumlah uang yang diperjanjikan, kepada tertanggung.

a. Kalau tertanggung meninggalkan dalam massa berlaku perjanjian, atau

b. Pada saat berakhirnya jangka waktu perjanjian

keperluannya suka rela.

3. Asuransi Sosial, ialah asuransi yang memberikan jaminan kepada masyarakat dan diselenggarakan oleh pemerintah, yaitu:
a. Asuransi kecelakaan lalu lintas (jasa raharja).
b. Asuransi TASPEN, ASTEK. ASKES, ASABRI. (Ananto Sun, 2006: 79)

\section{Mekanisme Pengajuan Asuransi Kecelakaan Kecelakaan}

Mekanisme pengajuan untuk mendapatkan asuransi memiliki beberapa prosedur serta hal-hal yang diperluhkan dalam memperoleh santunan yang dimaksud dan adapun prosedurnya dan hal-hal yang diperluhkan yaitu:
1. Cara memperoleh santunan
a. Menghubungi kantor Jasa Raharja terdekat
b. Mengisi formulir pengajuan dengan melampirkan:

2. Copy Laporan Polisi Lalu Lintas dari Kepolisian dan

Kecelakaan dari instansi berwenang lainnya.

a. Keterangan kesehatan dari dokter / RS yang merawat.

b. KTP / Identitas korban / ahli waris korban.

c. Formulir pengajuan diberikan Jasa Raharja secara cumaCuma

3. Bukti lain yang diperluhkan yaitu
a. Dalam hal korban luka-luka dengan melampirkan
Kwitansi biaya
rawatan dan
pengobatan yang asli dan sah.
b. Dalam hal korban meninggal dunia dengan melampirkan Surat kartu keluarga/surat nikah ( bagi yang sudah menikah )

4. Ketentuan lain yang perlu diperhatikan yaitu :
a. Jenis Santunan
b. Santunan berupa penggantian biaya rawatan dan pengobatan (sesuai ketentuan)
c. Santunan kematian
d. Santunan cacat tetap

5. Ahli Waris
a. Janda atau dudanya yang sah
b. Anak-anaknya yang sah




\section{c. Orang tuanya yang sah}

6. Daluarsa

Hak santunan menjadi gugur/daluarsa jika :

a. Permintaan diajukan dalam waktu lebih dari 6 bulan setelah terjadinya kecelakaan

b. Tidak dilakukan penagihan dalam waktu 3 bulan setelah hak dimaksud disetujui

Sehubungan dengan asuransi itu sendiri, perlu kiranya penulis masukkan tentang hal-hal yang menyebabkan berakhirnya perjanjian asuransi yang memiliki hubungan yang sangat signifikan yaitu sebagai berikut :

1. Karena Terjadi Evenemen

2. Karena Jangka Waktu Berakhir

3. Karena Asuransi Gugur

4. Karena Asuransi Dibatalkan

Adapun penjelasan tentang sebab-sebab berakhirnya asuransi dapat diuraikan sebagai berikut:

1. Karena Terjadi Evenemen

Dalam asuransi jiwa, satu-satunya evenemen yang menjadi beban penanggung adalah meninggalnya

tertanggung. Terhadap evenemen inilah diadakan asuransi jiwa antara tertanggung dan penanggung. Apabila dalam jangka waktu yang diperjanjikan terjadi peristiwa meninggalnya tertanggung, maka penanggung berkewajiban membayar uang santunan kepada penikmat yang ditunjuk oleh tertanggung atau kepada ahli warisnya. Sejak penanggung melunasi pembayaran uang santunan tersebut, sejak itu pula asuransi jiwa berakhir. Mengapa asuransi jiwa berakhir sejak pelunasan uang santunan, bukan sejak meninggalnya tertanggung (terjadi evenemen). Menurut hukum perjanjian, suatu perjanjian yang dibuat oleh pihak-pihak berakhir apabila prestasi masingmasing pihak telah dipenuhi. Karena asuransi jiwa adalah perjanjian, maka asuransi jiwa berakhir sejak penanggung melunasi uang santunan sebagai akibat dan meninggalnya tertanggung. Dengan kata lain, asuransi jiwa berakhir sejak terjadi evenemen yang diikuti dengan pelunasan klaim.

2. Karena Jangka Waktu Berakhir

Dalam asuransi jiwa tidak selalu evenemen yang menjadi beban penanggung itu terjadi bahkan sampai berakhirnya jangka waktu asuransi. Apabila jangka waktu berlaku asuransi jiwa itu habis tanpa terjadi evenemen, niaka beban risiko enanggung berakhir. Akan tetapi, dalam perjanjian ditentukan bahwa penanggung akan 
mengembalikan sejumtah uang kepada tertanggung apabila sampai jangka waktu asuransi habis tidak terjadi evenemen. Dengan kata lain, asuransi jiwa berakhir sejak jangka waktu berlaku asuransi habis diikuti dengan pengembalian sejumlah uang kepada tertanggung.

3. Karena Asuransi Gugur Dalam ketentuanPasal 306 KUHD: "Apabila orang yang diasuransikan jiwanya pada saat diadakan asuransi ternyata sudah meninggal, maka asuransinya gugur, meskipun tertanggung tidak mengetahui kematian tersebut, kecuali jika diperjanjikan lain" Kata-kata bagian akhir pasal ini "kecuali jika diperjanjiknn lain" memberi peluang kepada pihak-pihak untuk memperjanjikan

menyimpang dari ketentuan pasal ini, misalnya asuransi yang diadakan untuk tetap dinyatakan sah asalkan tertanggung betul-betul tidak mengetahui telah meninggalnya itu. Apablia asuransi jiwa itu gugur, bagaimana dengan premi yang sudah dibayar karena penanggung tidak menjalani risiko? Hal ini pun diserahkan kepada pihak-pihak untuk memperjanjikannya.

Pasal 306 KUHD ini mengatur asuransi jiwa untuk pihak ketiga.
Dalam ketentuan Pasal 307 KUHD juga ditentukan: "Apabila orang yang mengasuransikan jiwanya bunuh diri, atau dijatuhi hukuman mati, maka asuransi jiwa itu gugur". Menurut Purwosutjipto, penyimpangan dari ketentuan ini masih mungkin, sebab kebanyakan asuransi jiwa ditutup dengan sebuah klausul yang membolehkan

penanggung melakukan prestasinya dalam hal ada peristiwa bunuh diri dan badan tertanggung asalkan peristiwa itu terjadi sesudah lampau waktu 2 (dua) tahun sejak diadakan asuransi. Penyimpangan ini akan menjadikan asuransi jiwa lebih supel lagi

4. Karena Asuransi batalkan Asuransi jiwa dapat berakhir karena pembatalan sebelum jangka waktu berakhir. Pembatalan tersebut dapat terjadi karena tertanggung tidak melanjutkan pembayaran premi sesuai dengan perjanjian atau karena permohonan tertanggung sendiri. Pembatalan asuransi jiwa dapat terjadi sebelum premi mulai dibayar ataupun sesudah premi dibayar menurut jangka waktunya. Apabila pembatalan sebelum premi dibayar, tidak ada masalah. Akan tetapi, apabila pembatalan 
setelah premi dibayar sekali atau beberapa kali pembayaran (secara bulanan), Karena asuransi jiwa didasarkan pada perjanjian, maka penyelesaiannya

bergantung juga pada kesepakatan pihak-pihak yang dicantumkan dalam polis.

Dan berdasarkan hasil wawancara dengan salah 1 responden pada tanggal 21 Maret Tahun 2010 mengatakan bahwa:

"Pemberian santunan Korban kecelakaan lalu lintas khususnya besaran dari masing-masing santunan dan atau jenis santunan baik meninggal dunia atau luka-luka tidak ada penjelasan secara resmi (interpelasi) dari PT. Jasa Raharja kepada korban kecelakaan serta batasan luka-luka seperti apa yang akan disantuni oleh PT. Jasa Raharja berdasarkan Peraturan Pemerintah itu"

\section{Pelaksanaan Asuransi Kecelakaan Lalu Lintas Pada PT. Jasa Raharja (Persero) Cabang Sulawesi Tenggara Perwakilan Kolaka}

Berdasarkan hasil kunjungan kelapangan terhadap responden yaitu korban kecelakaan, pengguna jalan dan para ahli waris masing-masing adalah an. Idul. AM sebagai korban, Arif sebagai pengguna jalan serta an. Ahkmar sebagai ahli waris pada tanggal 21 Maret 2010 bahwa: "pemberian santunan bagi korban kecelakaan baik korban luka-luka maupun meninggal dunia telah berjalan karena masih belum merata kepada masyarakat yang disebabkan karena pemahaman masyarakat tentang pengajuan klaim serta besaran dari masing-masing santunan dan atau jenis santunan baik meninggal dunia atau luka-luka tidak ada penjelasan secara resmi (interpelasi) dari PT. Jasa Raharja berdasarkan Peraturan Pemerintah Nomor 18 Tahun 1965 dan juga memang kendalanya adalah Staf PT. Jasa Raharja (Persero) Cabang Sulawesi Tenggara Perwakilan Kolaka hanya 2 orang dan mengingat jumlah kecelakaan tidak merata untuk masing-masing wilayah dan Negara bahwa kecelakaan lalu lintas dan cara pencegahannya terus berkembang dengan berbagai upaya terus dilakukan untuk mengurangi jumlah kecelakaan munculnya risiko di jalan raya merupakan dampak dari kebutuhan pengguna jalan dan juga volume kendaraan yang makin bertambah" Pelaksanaan asuransi Sosial dalam kecelakaan lalu lintas sudah berjalan sebagaimana apa yang menjadi ketentuan undangundang dan peraturan pemerintah itu sendiri akan tetapi ada beberapa hal yang menghambat pelaksanaan asuransi sosial dalm kecelakaan lalu lintas termasuk akan kesadaran masyarakat akan hukum yang dianggap sebagai hal yang begitu penting termasuk ketika masyarakat memiliki kendaraan bahwa mutlak memiliki surat keterangan berlalu lintas dari kepolisian Sat Lantas" Hal ini tampak dari arus lalu lintas tanpa adanya upaya-upaya pengamanan yang baru, semua pengguna jalan sangat mungkin terkena risiko kecelakaan seiring dengan meningkatnya lalu lintas kendaraan. Upaya-upaya keselamatan baru itu terutama dilakukan karena makin banyaknya jenis kendaraan bermotor, kebutuhan perjalanan dengan kecepatan tinggi, dan perlunya pembagian pemakai jalan baik untuk pejalan kaki, pengendara sepeda motor, dan juga kendaraan lainnya.Untuk mengurangi risiko 
terjadi kecelakaan, tidak mungkin dilakukan dengan cara mengurangi keinginan untuk melakukan perjalanan. Sesuatu yang mungkin adalah mengurangi lama dan intensitas kemungkinan para pengguna jalan raya terkena risiko kecelakaan Sejak awal, kebijakan pemerintah dan berbagai proyek harus memasukkan keamanan dalam sistem lalu lintas yang akan diterapkan.

Pola-pola penggunaan tanah harus memperhitungkan jumlah, panjang perjalanan yang dilakukan orang, pilihan rute, serta mode angkutan yang digunakan. Tempat tinggal penduduk dengan tempat di mana mereka harus bekerja, pergi ke sekolah, berbelanja, dan mendapatkan berbagai kebutuhan mereka, seperti untuk rekreasi dan hiburan, secara keseluruhan harus berdekatan. Masyarakat perlu diberi pilihan untuk berjalan kaki, menggunakan sepeda, dan transportasi umum dibandingkan dengan menggunakan kendaraan pribadi. Pengurangan jumlah kendaraan bermotor, khususnya di sejumlah tempat di mana pengguna jalan berisiko mudah terkena kecelakaan, akan mengurangi kemungkinan kecelakaan itu sendiri. Pengambil kebijakan perlu menerapkan peraturan yang mengurangi kendaraan pribadi memasuki pusat kota . Demikian pula menerapkan kewajiban bayar untuk truk atau angkutan wisata pada tempat-tempat tertentu selama waktu tertentu dapat efektif mengurangik Kecelakaan. Masyarakat perlu didorong untuk menggunakan mode dan perjalanan yang lebih aman. Penyediaan transportasi publik baik dengan menggunakan bus ataupun kereta akan mengurangi jarak perjalanan, yang berarti mengurangi risiko. Di banyak negara maju, kebijakan transportasi nasional merupakan gabungan antara kombinasi transportasi umum dan memperbaiki fasilitas bagi pejalan kaki dan rute bersepeda. Sejumlah upaya dilakukan, antara lain, dengan cara membuat skenario meminimkan kemungkinan terkena risiko kecelakaan lalu lintas jalan, perencanaan dan desain jalan untuk keamanan, audit keamanan, melindungi pejalan kaki dan pengguna sepeda, dan desain kendaraan yang makin pintar Sehingga mengurangi kecelakaan.Pemerintah harus menerapkan peraturan keamanan jalan dan berkendaraan dengan jalan menerapkan aturan batas kecepatan, batasan konsumsi alkohol bagi pengendara, mengenalkan masalahmasalah kelelahan bagi pengemudi, penggunaan sabuk keselamatan, dan penggunaan helm. Sementara pengelola fasilitas kesehatan perlu memperbaiki penanganan korban kecelakaan sebelum sampai ke rumah sakit. Mereka harus meningkatkan pengetahuan soal penanganan kecelakaan di lokasi kejadian, akses ke unit gawat darurat, perawatan oleh unit gawat darurat, dan juga perbaikan penanganan di rumah sakit. Dari laporan Badan Kesehatan Dunia (WHO) dan Bank Dunia, terdapat sejumlah pesan, antara lain, sistem lalu lintas jalan adalah sistem yang kompleks dan berisiko membahayakan keselamatan manusia sehingga harus dikurangi hal-hal yang bisa memunculkan bahaya. Keselamatan di jalan raya adalah tanggung jawab bersama yang membutuhkan komitmen dan juga keterlibatan bersama. 
6. Hambatan

Santunan

Kecelakaan

dan Cara Penyelesainnya.

1. Pelaksanaan asuransi Sosial dalam kecelakaan lalu lintas sudah berjalan sebagaimana apa yang menjadi ketentuan undang-undang dan peraturan pemerintah itu sendiri akan tetapi ada beberapa hal yang menghambat pelaksanaan asuransi sosial dalm kecelakaan lalu lintas termasuk akan kesadaran masyarakat akan hukum yang dianggap sebagai hal yang begitu penting termasuk ketika masyarakat memiliki kendaraan bahwa mutlak memiliki surat keterangan berlalu lintas dari kepolisian Sat Lantas yang kemudian wajib membayar iuran wajib yang bertujuan menutupi akibat kekurangan dalam rangka menanggulangi risiko dan pemhaman akan masyarakat tentang pengajuan klaim asuransi ketika mendapatkan suatu kerugian, bahaya sehingga perlu adanya tindakan preventif sebagai langkah persiapan dalam rangka menangulangi suatu risiko yang tidak dapat ditanggulanginya sendiri akibat keadaan yang mendesak karena risiko tadi sehingga dapat mengetahui Haknya pada PT. Jasa Raharja (Persero) Cabang Sulawesi Tenggara Perwakilan Kolaka.

2. Pemahaman masyarakat tentang pengajuan klaim sudah hampir seluruhnya dipahami masyarakat kabupaten Kolaka karena perusahaan asuransi berupaya secara maksimal melakukan giat-giat dilapangan baik berupa sosialisasi tentang pengenalan asuransi sosial dalam kecelakaan lalu lintas yang bekerja sama dengan pihak-pihak yang terkait serta kerja sama semua pihak dalam hal ini masyarakat pengguna jalan yang seyogyanya menjalin keterpaduan dan kerja sama kaitannya bahwa semua masyarakat mutlak mendapatkan asuransi sebagai wujud dan implementasi dari keinginan undang-undang dan pemerintah dalam mewujudkan masyarakat yang sejahtera yang pada dasarnya dapat dikatakan bahwa tujuan asuransi sosial itu memang berkaitan dengn perlindungan terhadap jaminan sosial terhadap masyarakat yang sesuai dengan usaha-usaha pemerintah untuk mewujudkan program kesejahteraan sosial dengn kata lain merupakan peruwjudan suatu penyelenggaraan jaminan sosial (Social scurity), artinya bahwa asuransi sosial dalam kecelakan lalu lintas benarbenar bermaksud untuk memberikan suatu jaminan terhdap segala kemungkinan terjadinya suatu kerugian diluar kemampuan masyarakat sendiri, karena kerugian yang disebabkan diluar kemampuannya serta tidak bisa ditanggulangi sendiri, maka wajiblah segera dimbil alih. 
3. Kurang berperannya petugas keliling dalam mendapatkan informasi bagi korban kecelakaan lalu lintas pada Pt. Jasa Raharja (Persero) Cabang Sulawesi Tenggara Perwakilan Kolaka

Berdasarkan fakta yang terjadi di masyarakat, Jasa Raharja harus lebih membenahi diri dalam mencari solusi yang terbaik dan efektif untuk menyampaikan informasi kepada masyarakat luas dan dinamis walaupun banyak tantangan yang dihadapi. Menghadapi kondisi tersebut, Jasa Raharja melakukan langkah-langkah berupa program utama sebagai uapaya dalam memecahkan permasalahan yang ditimbulkannya yakni dengan melakukan perlindungan dengan 3 aspek yaitu:

4. Mengupayakan agar masyarakat mendapat kepastian perlindungan asuransi dari modal transportasi yang dipergunakannya

bekerjasama dengan dinas perhubungan, operator angkutan laut/udara atau organda.

5. Mengupayakan agar masyarakat yang memiliki kendaraan bermotor dan pengusaha angkutan umum dapat meningkatkan kesadarannya menyetorkan iuran wajib yang telah diikutinya bersamaan dengan pembayaran sewa rutin dan teratur agar dapat memenuhi kewajibannya membayar sumbangan wajib dana kecelakaan lalu lintas jalan (SWDKLLJ), agar masyarakat yang menjadi korban akibat penggunaan kendaraan bermotor mendapat kepastian akan haknya.

6. Menempatkan petugas Jasa Raharja di daerah kabupaten untuk mendekatkan pelayanan kepada masyarakat dalam rangka pemberian perlindungan asuransi bahkan kalau perlu menambah karyawan demi tercapainya tatanan organisasi yang baik dan terarah kaitannya dengan pencapaian usaha pemerintah dalam memberikan kesejahteraan kepada masyarakat secara keseluruhan. Sehingga menjadi korban mati atau cacad tetap agar segera mendatangi perusahan asuransi sosial dalam kecelakan lalu lintas serta giat-giat pada PT. Jasa Raharja dan instansi terkait yang tergolong masih minim perakteknya untuk terjun langsung dilapangan sekaligus mensosialisasikan keberadaan PT. Asuransi Jasa Raharja serta tujuannya karena mengingat staf jasa raharja hanya 2 (data 2010) orang yang dtempatkan di perwakilan Kolaka sehingga untuk meningkatkan pelayanan santunan asuransi dengan pelayanan jemput bola ditengah masyarakat seluas-luasnya.

\section{E. Kesimpulan}

Berdasarkan hasil penelitian dan pembahasan, maka dapat disimpulkan sebagai berikut:

1. Pelaksanaan asuransi sosial dalam kecelakaan lalu lintas merupakan suatu perjanjian 
dimana mengharuskan dan atau mewajibkan seseorang membayar atau menyerahkan sesuatu dan pada khususnya PT. Jasa Raharja (Persero) Cabang Sulawesi Tenggara perwakilan Kolaka bahwa pengajuan klaim dan pemberian santunan kecelakaan lalu lintas berdasarkan undang-undang No. 34 Tahun 1964 jo PP No. 18 Tahun 1965 dan pemberian santunan yang diberikan terhadap korban kecelakaan lalu lintas jalan berdasarkan pasal 11 PP No. 18 Tahun 1964, surat keputusan Menteri Keuangan RI No. 416/KMK.06/2001 serta didasarkan pada keputusan direksi. Santunan akan diberikan kepada setiap orang yang berada diluar alat angkutan lalu lintas jalan yang menimbulkan kecelakaan, yang menjadi korban akibat kecelakan yang disebabkan alat angkutan lalu lintas jalan tersebut dengan pengecualian yang tercantum dalam pasal 13 PP No. 18 Tahun 1965. Pelaksanaan asuransi sosial kecelakaan lalu lintas jalan merupakan suatu upaya pemerintah dalam memberikan perlindungan jaminan sosial kepada masyarakat khususnya korban kecelakaan lalu lintas jalan. Pihak jasa raharja tetap memberikan dana santunan kepada korban kecelakaan lalu lintas jalan yang disebabkan oleh alat angkutan lalu lintas jalan yang lali membayar sumbangan wajib, yang kemudian pihak jasa raharja dapat menuntut balik kepada pemilik kendaraan penyebab kecelakaan yang lalai dalam pembayaran sumbangan wajib untuk membayar semua penggantian kerugian yang telah dikeluarkan oleh pihak jasa raharja dan mengenai hal ini diatur dalam pasal 14 huruf d PP No. 18 Tahun 1965. Dalam perjalanannya PT. Jasa Raharja (Persero) Cabang Sulawesi Tenggara perwakilan Kolaka dalam memberikan santuanan kepada korban kecelakaan lalu lintas telah berjalan sesuai dengan undang-undang Nomor 34 Tahun 1964 Jo Peraturan Pemerintah Nomor 18 Tahun 1965, akan tetapi belum dapat dikatakan bahwa asuransi kecelakaan belum jamin semua pengguna jalan yang disebabkan karena hambatan berupa pemhaman masyarakat yang masih kurang, termasuk keadaan ekonomi dan keuangan dewasa ini belum mengizinkan meskipun itu sumber dana itu bersumber dari sumbangan wajib masyarakat itu sendiri yang pelaksanaannya berupa sumbangan tahunan yang wajib dibayar serta dari pemerintah mempunyai penyertan modal sepenuhnya atau sebagian besar secara langsug atau tidak langsung dalam hal ini urusan pendapatan, pembiayan dan pengawasan menurut dan atau berdasarkan ketentuan undangundang dan atau peraturanperaturan pelaksanaannya haruslah penuh penghayatan dan kesadaran secara kolektif dari seluruh pihak yang terkait. Dan sebagai usul bahwa pengelolaan dana pertanggungan dana kecelakaan baru diberikan setelah peristiwa kecelakaan terjadi sehingga UU ini dinilai hanya bersifat kuratif yang hanya mempunyai daya mengobati/ meringankan sehingga itulah penulis mengusulkan kiranya UU ini dapat direvisi dan lebih bersifat preventif yang mempu 
memberikan perlindungan bagi semua pengendara dijalan dan dalam hal iuran/sumbangan wajib dapat dialokasikan untuk kegiatan-kegiatan lain, seperti sosialisasi lalu lintas, sosialisasi tata cara pengajuan klaim dan berbagai kegiatan pendidikan lainnya. Berdasarkan kesimpulan diatas, terdapat beberapa saran yang penulis kemukakan berikut ini :

Pertama, Meningkatkan pelayanan santunan asuransi dengan pelayanan jemput bola, artinya langsung terjun ke lapangan dengan mengutamakan 4 prinsip dasar yaitu:

\section{a. Perinsip Kepentingan}

Dengan adanya perinsip kepentingan maka akan tercipta rasa kepemilikan yang menunjukkan hubungan antara pemilik dengan harta benda yang artinya bahwa pihak penanngung dan tertanggung bersama-sama memiliki kepentingan satu sama lain dalam mewujukan kepntingan bersama maka perlu adanya rasa kepemilikan.

\section{b. Perinsip Jaminan}

Perinsip jaminan merupakan dasar berpikir terhadap suatu perbuatan dalam pertanggungan sehingga Jaminan akan muncul karena adanya kerugian dan dengan adanya kerugian yang diderita tertanggung, maka dia tidak boleh memperoleh keuntungan dari ganti rugiyang diberikan oleh penanggung dan ganti rugi bertujuan:

1. Mengembalikan tertanggung keposisinya semula artinya sebelum mendapatkan dan atau ditimpa musibah atau bencana

2. Menghindarkan tertanggung dari bangkrut

\section{c. Perinsip Kepercayaan}

Pada prinsip ini kepercayaan dari pihak penanggung mendapat tempat yang terhormat karena bila tidak ada kepercayaan dari penanggung, maka penutupan asuransi akan gagal dan kepercayaan itu terutama atas keterangan yang diberikan oleh tertanggung dengan maksud seluk beluk barang dan atau objek yang diasuransikan akan ditutup penjaminannya

\section{d. Perinsip Itikad Baik}

Bahwa dalam itikad baik ini seharusnya dimiliki oleh masingmasing pihk antara teranggung dan penanggung dengan kata lain sudah seharusnya kepercayaan dari pihak penanggung diimbangi dengan itikad baik yaitu dengan memberitahukan segala bentuk informasi mengenai ditutup atau tidaknya pertanggungan.

Kedua, Mengoptimalkan peran petugas keliling mencari informasi korban laka lantas jalan dan bekerjasama dengan pihak kepolisian lalu lintas di polres maupun polsek, rumah sakit, kerumah korban atau ahli waris korban untuk memberi layanan serta memberikan informasi berupa pengumuman dalam rangka Mengupayakan agar masyarakat yang memiliki kendaraan bermotor dan pengusaha angkutan umum dapat meningkatkan kesadarannya menyetorkan iuran wajib yang telah diikutinya bersamaan dengan pembayaran sewa rutin dan teratur agar dapat memenuhi kewajibannya membayar sumbangan wajib dana kecelakaan lalu lintas jalan (SWDKLLJ), agar masyarakat yang menjadi korban akibat 
penggunaan kendaraan bermotor mendapat kepastian akan haknya serta pencantuman berupa persyaratan pengurusan santunan Jasa Raharja bahkan kalau perlu menambah karyawan demi tercapainya tatanan organisasi yang baik dan terarah kaitannya dengan pencapaian usaha pemerintah dalam memberikan ksejahteran kepada masyarakat secara kesluruhan.

Ketiga, Meningkatkan pelayanan berkas pengajuan santunan syarat sudah lengkap dan sah, yang sebelumnya diprogramkan selesai satu hari, sekarang ditingkatkan menjadi lima jam maximum sejak mengajukan berkas klaim.

Keempat,

Melakukan

Sosialisasi kepada masyarakat bekerja sama dengan pihak yang terkait kaitannya dengan keberadaan asuransi sebagai wujud kepedulian pemerintah dalam memberikan kesejahteraan sosial bagi masyrakat secara luas terkhusus masyrakat kabupaten Kolaka serta menghimbau kepada masyarakat pengguna jalan raya hendaknya tertib dan berhati-hati untuk menjaga keselamatan bersama, dan laporkan segera bila terjadi kecelakaan lalu lintas kepada kepolisian dan Jasa Raharja terdekat agar mendapatkan hak yang di atur dalam UU Nomor 34 Tahun 1964.

\section{DAFTAR PUSTAKA}

Adi Satrio, Kamus Ilmiah Populer, Jakarta : Visi 7, 2005.

Ahmadi Miru, Sakka Pati. Hukum Perikatan, Makassar : Raja Grafindo Persada, 2008

Ananto Sun., Hukum Perjanjian Asuransi, Semarang : Widya Karya, 2006.
Artikel Posted One Rabu, Edo Rusyanto, Jaminan Sosial. 2009.

Komariah, Hukum Perdata, Malang : UUM Press, 2001.

Badzrulaman, Mariam Darus, Hukum Perdata Buku III dengan penjelasan. Bandung : Penerbit Alumni, 1983.

Nurhaedah, Nurhaedah. Analisis Hukum Terhadap Asuransi Kendaraan Bermotor Bagi Pemilik Kendaraan Sebagai Tertanggung. Pleno Jure, 2015, 4.5: 28-41.

Muhammad Syakir Sula, Konsep dan Operasional Asuransi Syariah, Jakarta: Gema Insani, 2004.

Abbas, Ilham, Salle Salle, and Hardianto Djanggih. "Corporate Responsibility Towards Employees Welfare." Yuridika 34.1 (2019): 37-53.

Peraturan Pemerintah Republik Indonesia Nomor 18 Tahun 1965, Tentang KetentuanKetentuan Pelaksanaan Dana Kecelakaan Lalu Lintas, Jakarta Pusat

Rachmad Baro, Teori Imu Hukum, Makassar : Umitoha Ukhuwah Grafika, 2001

Subekti, Jaminan-Jaminan Untuk Pemberian Kredit Menurut Hukum Indonesia, Bandung : Alumni, 1978

Suharso, Ana Retnoningsih, Kamus Besar Bahasa Indonesia, Semarang : Widya Karya, 2005

Subekti, Tjitrosudibio, Kitab Undang-Undang Hukum

Perdata, Jakarta : Pradnya Pramita, 1999

Sudikno Mertukusumo, Mengenal Hukum, Yokyakarta : Liberty, 1986 
Syamsul Anwar, Hukum Perjanjian Syariah: Studi tentang Teori Akad dalam Fikih Muamalat, Jakarta : Radjawali Persada, 2007

Undang-Undang Nomor 34 Tahun 1964, Tentang Pelaksanaan Asuransi Sosial Kecelakaan Lalu Lintas

Undang-Undang Perkawinan Nomor 1 Tahun 1974, Pasal 31 ayat 2.

http://hukumonline.com/klinik_detail .asp?id=5517 diakses tanggal 21 september 2011

http://id. Wiipedia.org/wiki/Jasa Raharja diakses tanggal 3 Oktober 2013

http://www.ugm.ac.id/id/berita/3086asuransi.kecelakaan.belum.ja min.semua. pengguna.jalan diakses tanggal 30 September 2013 